\title{
ANALYSIS OF EFFICIENCY AMONG RICE FARMERS IN OYO STATE, NIGERIA
}

ADESHINA, Wasiu Olawale; OLOGBON, Olugbenga Adesoji Christopher and

\section{DOWU, Adewunmi Olubanjo}

Department of Agricultural Economics and Farm Management

Olabisi Onabanjo University, Yewa Campus, Ayetoro, Ogun State, Nigeria

Correspondence Author Email: adeshina.wasiu@yahoo.com

\section{ABSTRACT}

Increased rice productivity for years is not a solution if rice farming efficiency cannot be sustained for the next hundred years. The study analysed the efficiency of rice farmers in Oyo State. A multistage sampling procedure was employed to select 128 rice farmers for the study. Primary data were obtained with the aid of well-structured questionnaire and interview schedule. Descriptive statistics and stochastic frontier model were employed in the analysis of the data. Majority $(78.1 \%)$ of the rice farmers had one form of education or the other while the age of rice farmers ranges from 25 to 78 year and mean age of 47 years. The stochastic frontier results (Maximum Likelihood Estimates) revealed that farm output increases with farm size, hired labour, and fertilizer but decreases with herbicides Also, technical efficiency of the farmers increases with formal education, farming experience, allocative efficiency and economic efficiency of 88.5 percent 66.9 percent and 58.3 percent respectively showed that there is room for improvement in technical efficiency by 11.5 percent allocative efficiency by 33.1 percent and economic efficiency by 41.7 percent with the presen technology. Policy option requires the rice farmers to reduce the use of agro chemical. Farmers should expand their farm land to ensure efficient utilization of resources. Above all, formal education and adult literacy education should be strengthened among the rice farmers.

Keywords: Rice farmers, Efficiency, Stochastic frontier model, Oyo State

Accepted Date: 6 September 2018

\section{INTRODUCTION}

\section{Background of the study}

Agriculture is an important sector of the economy of most nations, although its importance varies from country to country, depending on the stage of economic development (Oladeebo and Fajuyigbe 2007). Nigerian economy grew from an agricultural base with rice being one of the food crops grown in the country. Productivity is generally defined as the level of output in relation to levels of resources employed in a given period of ime. It is the rates of time. It is the rates of fl compared with rates of flow of resources such as Adenegan, 2016).

Globally, rice is a very important food crop. It is an ancient crop consumed as healthy and staple food by more than half of the worldp by 2014). Rice is one of te mujor stadiriet produced in Nigeria. The country is the highest producer of rice in the West African Sub-region (Ahmadu and Erhabor, 2012). It has attained a staple food status and also became a major source of calories for the urban poor (Idiong, 2007). Furthermore, it has been emphasized that rice is not Fuly a key source of food, but also a major major por poor. In rice producing areas, the enterprise provides employment for more than $80 \%$ of the nhabitants in various activities along the production/distribution chain from cultivation to consumption (Ajoma et al., 2016)

Rice is grown virtually in all the agro-ecological zones in Nigeria. This is because Nigeria has ideal climatic conditions, which are akin to that of South East Asia where the crop is produced for export (Ajoma (Ajoma et al., 2016). Since a large portion of maize consumption; rice is the most important grain with 
regard to human nutrition and calorie intake (Oladimeji and Abdulsalam, 2013). Rice provides more than one fifth of the calorie consumed worldwide by human species, though relatively lower in protein compare to other cereals, it contains a better balance of amino acids (Oladimeji and Abdulsalam, 2013).

Rice is an increasingly important crop in Nigeria. It is relatively easy to produce and it is grown for sale and for home consumption(Kadiri et al., 2014). In some areas there is a long tradition of rice growing, but for many, it is considered a luxury food for special occasions only. With the increased availability of rice, it has become part of the everyday diet of many people in Nigeria. There are many varieties of rice grown in Nigeria; some of these are traditional varieties while others have been introduced into the country.

Nigeria is the leading consumer and largest producers of rice in Africa and simultaneously one of the largest rice importers in the world. As well as an important food security crop, it is an essential cash crop for it is mainly produced by small-scale producers who commonly sell about 80 per cent of total production and consume only about 20 per cent (Oladimeji and Abdulsalam, 2013). However, domestic supply of rice has continued to fall short of demand and importation is undertaken to make up the shortfall.

\section{Problem statement}

Although rice production has increased during the last two decades in Nigeria, the country's production figure is far below the national requirement (Osanyinlusi and Adenegan, 2016). Nigeria has been a major consumer and number two importer of rice in the world, importing 2 million metric tons of rice annually (Munonye, 2016). The high importation is however linked to the increasing population being witnessed in Nigeria and also increasing share of rice in Nigerian diet. In order to meet the increasing demand for rice, Nigeria has resorted importation of milled rice to bridge the gap and supply.

Nigeria rice imports increased significantly in the last quarter of 2011 caused by Government's announcement of high levies to be imposed twice within the year 2012 and came after the production shortfall after the flooding. Nigeria imports broken rice, rice husked and milled rice (Munonye, 2016) In 2001-2005, a total of over 55 million tons of rice was imported into the country (FAO, 2012). According to FAO (2012), Nigeria spen $\$ 403,578,202$ in the importation of semimilled/wholly milled in 2010 which is about 677,016 tons. This was followed by husked (brown) rice $\$ 78,984,737$ about 32,122 tons(FAO, 2012). In 2006 over $60 \%$ of imported rice (milled equivalent) originated from Thailand, countries such as Bril, United States, UAE and India India started playing a larger role in the following years Nigeria spent $\mathrm{N} 365$ billion ( $\$ 2.2$ billion) on importation with about 8000 bags smuggled daily from Benin Republic (Munonye, 2016).

A major constraint to domestic production of rice in Nigeria is connected to poor resource utilization, environmental and institutional factors. Rice farmers in Nigeria are not getting maximum return from the resources committed to their enterprises leading to a decline in per capita food production (Okoruwa et al. 2006 in Osanyinlusion (Okorwa et al., 2006 in Osanyinlusi an Adenegan, 2016). Its production has also mainly been in the hands of small-scale resource poo farmers who depend heavily on the use of traditional technologies, which result in low productivity.

Nigeria has about 4.8 million hectares of potentia land area for rice production but only about $36 \%$ is under cultivation with the rice farmers cultivating average farm size of less than 2 hectares (Ahmad and Erha increased rice production could be achieved by increasing rice productivity through efficiency in the use of the land and other scarce productive resources. But studies have shown that in Nigeria, most resources are not efficiently used in production (Ahmadu and Erhabor, 2012). The question now is, what are the factors responsible for the inefficiency of the farmers in the use of resources? It is with a view to provide answer to this question that this study was designed. The study is timely and needful now that the Nigeria timely and needful now that the Nigeria government is deternined to boost rice production and there is little study of this nature on rice, especially in Oyo State of Nigeria. Where such study exists, it was treated as a part of a study and hence might not be considered in detail.
Technical efficiency is the ability to achieve a higher level of physical output given a small level of production input. Hence the technical efficiency of rice farmers in the study area was needed to be measured to enable us know how efficient rice production is in the state and also became imperative to assess factors underlying inefficiency in the use of resources that will enhance small scale rice farmers to be efficient and for designing policies to meet the needs and well-being of rice farmers.

The study seeks to achieve the following specific objectives: to examine the socio-economic characteristics of the rice farmers; estimate the level and identify the determinant of technical and cost efficiency among rice farmers in Oyo State of Nigeria.

\section{Conceptual and Analytical Framework}

Efficiency measurement and the procedure of maximum likelihood estimation are the basic theoretical constructs on which this study is conceptualized. In economic analysis, much is concerned with the technical and economic efficiencies or resource transformation and allocation (Coelli et al.,2005). Production efficiency is concerned with the relative performance of the process used in transforming inputs into output. The concept of efficiency goes back to the pioneering work of Farrel (1957) as cited by Fasasi (2007) who distinguishes between three types of efficiencies: technical efficiency (TE), allocative efficiency (AE), and economic efficiency (EE).

Technical efficiency in production is the physical ratio of product output to the factor input, the greater the ratio, the greater the magnitude of technical efficiency. Allocative efficiency is concerned with choosing optimal sets of inputs. A firm is allocatively efficient when production occurs at a point where the marginal value product is equal to the marginal factor cost. Economic efficiency is a situat technical and allocative efficiencies. The simultaneous achieventent of both efficient condition according to Heady (1952) as cited by Fasasi (2007) occurs when price relationship are employed to denote maximum profits for the firm or when choice indicators are employed to denote the maximization of other economic objectives. So, economic efficiency refers to the choice of the best combination for a particular level of output which is determined by both input and output prices. Farrel's measure of efficiency depends on the existence of the efficient production function with which observed performance of a firm can be compared. A production function based on the "best" practical results would have to be used as a reference for measuring individual performance. However, due to the problem of complication, "best" obtained than to set up some che some diagrams of sever fins ob isoqued fiom scattered least ex of several firms an isocuant showing the least exacting standard of efficiency assumption of convexity to the origin and non-positive slope at

The stochastic efficiency frontier models independently proposed by Meeusen and Vanden Broeck (1977) and extended by Jondrow et al(1982) cited by Fasasi (2007) was used in analyzing the data. It allows for the estimation of individual firm efficiency level with both time variations and cross-sectional data. The stochastic efficiency frontier production function is defined by: $\mathrm{Yi}=\mathrm{F}(\mathrm{Xi}, \mathrm{b}) \exp (\mathrm{Vi}-\mathrm{Ui}) \mathrm{i}=1,2, \ldots, \mathrm{N}$

Where:-Yi= Output of ith firm, $\mathrm{Xi}=$ corresponding ( $M \times Z$ Z) vector of inputs, $\beta=$ vector of unknown parameter to be estimated., $\mathrm{Vi}=$ Symmetric error component that accounts for random effects and exogenous shock., $\mathrm{Ui}<\mathrm{O}=\mathrm{a}$ one - sided error component that measures technical inefficiency.

Estimation of inefficiency effect, - U from statistical noise, $\mathrm{V}$ is accomplished by estimating the mean of conditional distribution of $U$ given $V$ expressed as:

$\frac{U}{e}=\mu_{i}+\sigma *\left(f * \frac{-\mu_{i}}{\sigma *}\right)\left[1-F\left(\frac{\mu_{i}}{\sigma *}\right)\right]$

Where :-

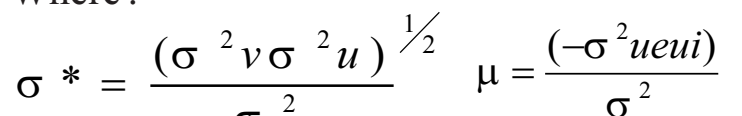

$\mathrm{f}=$ standard density function, and

$\mathrm{F}=$ standard distribution function

This is done by means of maximum likelihood

estimation (MLE), which involves the estimation 
of population parameters such that the probability density for obtaining the actual sample observation that have been obtained from the population is greater than the probability density obtainable with any other assumed values (estimations) of the population parameter (Ogundari and Ojo, 2007). The MLE method provides estimators that are asymptotically consistent and efficient. The parameters of the stochastic frontier function model are estimated by the method of maximum likelihood, using the computer program FRONTIER version 4.1 (Coelli et al.,2005).

\section{METHODOLOGY}

\section{Study area}

The study area was Oyo State in southwest, Nigeria. Oyo, usually referred to as Oyo State to distinguish it from the city of Oyo, is an inland state in south-western Nigeria, with its capital at Ibadan. It is bounded in the north by Kwara State, in the east by Osun State, in the south by Ogun State and in the west partly by Ogun State and partly by the Republic of Benin. Oyo State covers approximately an area of 28,454 square kilometers and is ranked 14 th by size. The landscape consists and is ranked 14 h of old hard rocks and dome shaped hills, which rise gently from about 500 meters in the southern part and reaching a height of about 1,219 metre above sea level in the northern part. Some principal rivers such as Ogun, Oba, Oyan, Otin, Ofiki, Sasa, Oni, Erinle and Osun river originate in this highland.

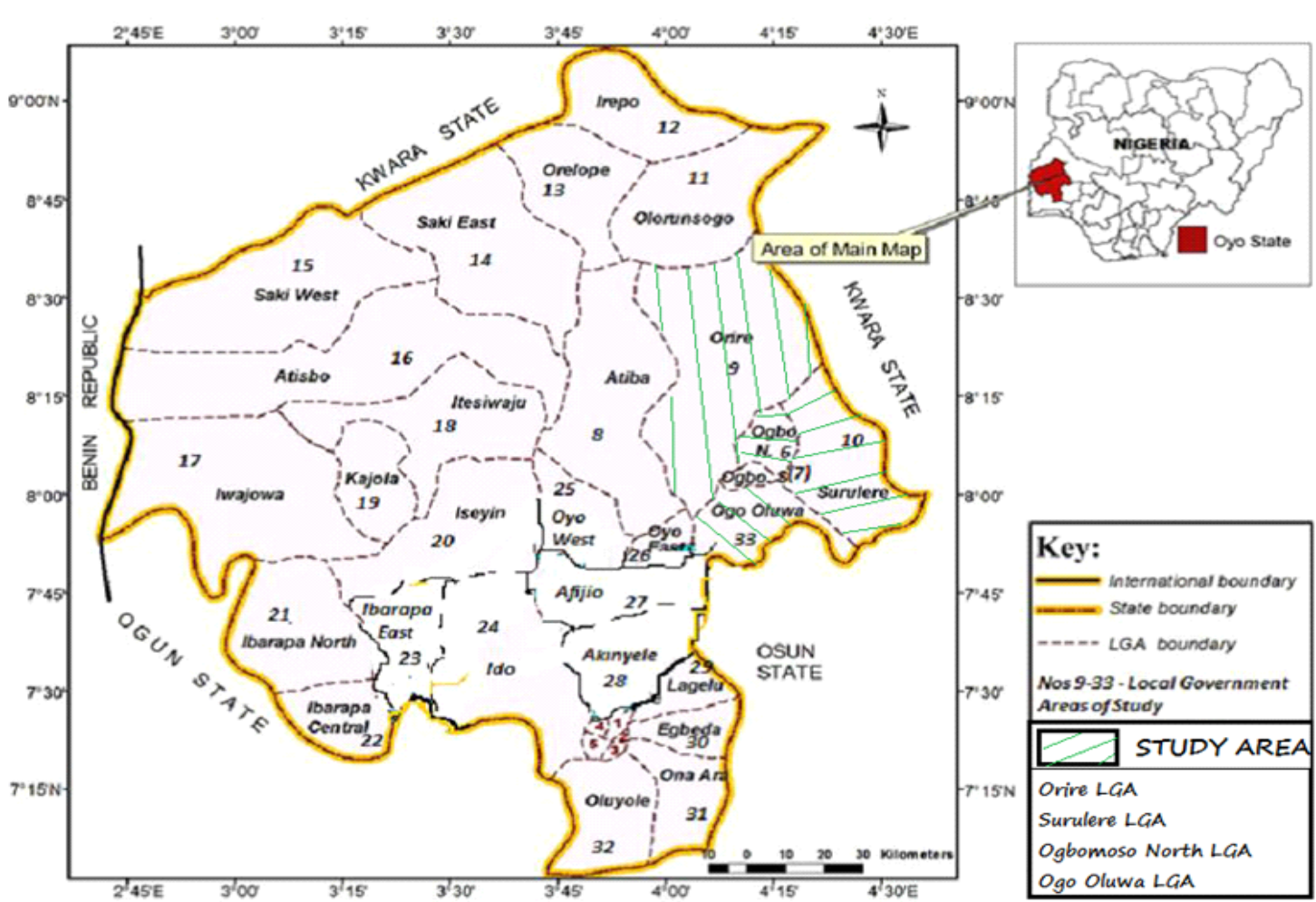

Figure 3.1: Map of Oyo State showing the study area

Agriculture is the main occupation of the people of Oyo State. The climate in the state favours the cultivation of crops like maize, yam, cassava, millet, rice, plantains, cocoa, palm produce, cashew, etc. There are a number of government farm settlements in Ipapo, Ilora,

Ogbomosho, Iresaadu, Ijaiye, Akufo and Lalupon. There is abundance of clay, kaolin and aquamarine. There are also vast cattle ranches at Saki, Fasola and Ibadan, a dairy farm at Monatan in Ibadan and the statewide Oyo State Agricultural Development Programme with headquarters at Saki. A number of international and federal agricultural establishment are located in the state.

cion, sampling technique and Primary data was usc which was obtained through the use of wellstructured questionnaire. The sampling frame for this study consisted of farmers growing rice under various cropping systems in the study area.

Multi-stage sampling procedure was used to select the respondents for the study. Oyo State comprises thirty three (33) Local Government Areas out of which seventeen (17) are producing rice and only 255 rice farmers are registered with the Oyo State Agricultural Development Programme. Following a multi-stage sampling procedure, in the first stage, $25 \%$ of the rice producing Local Government Area were selected purposely because of the high number of rice farmers in the area. And lastly, 50\% of the total rice farmers in each local government area were selected because of time and the remote location of the rice farmers in the study area.

\begin{tabular}{|c|c|c|c|c|c|}
\hline $\begin{array}{l}\text { Study } \\
\text { Area }\end{array}$ & $\begin{array}{l}\text { Local } \\
\text { govt in } \\
\text { the state }\end{array}$ & $\begin{array}{c}\text { Rice } \\
\text { producing } \\
\text { LGAs } \\
\end{array}$ & $\begin{array}{l}\text { Purposive Selected } \\
\text { LGAs }(25 \%)\end{array}$ & $\begin{array}{c}\text { No of rice } \\
\text { farmers in } \\
\text { selected LGAs }\end{array}$ & $\begin{array}{c}\text { Selected rice } \\
\text { farmers }(50 \%)\end{array}$ \\
\hline Oyo & 33 & 17 & Ogoluwa & 90 & 45 \\
\hline \multirow[t]{3}{*}{ State } & & & Surulere & 100 & 50 \\
\hline & & & Orire & 35 & 18 \\
\hline & & & Ogbomoso North & 30 & 15 \\
\hline Total & 33 & 17 & 4 & 255 & 128 \\
\hline
\end{tabular}

\section{Methods of Data Analysis}

Descriptive statistics such as mean, frequency and percentage were used to discuss the socioconomic characteristics of the rice farmers. The Stochastic Frontier functions were used to capture technical and cost efficiency in the production process of the rice farmers.

\section{Technical and cost efficiencies of the rice} farmers

The Stochastic frontier production function model of Cobb-Douglas functional form was employed to estimate the farm level of efficiency of the rice farmers. The Cobb-Douglas functional form was used because it has been used in many empirical studies particularly those relating to developing country agriculture and the functional form meets the requirement of being self-dual i.e. it allows an examination of economic efficiency (Ambali et al. 列

$Y_{i}=f\left(X_{i} ; \beta\right) \exp V_{i}-\mu$

The technical efficiency of individual farmers is defined in terms of the ratio of observed output $\left(Y_{i}\right)$ to the corresponding frontier output $\left(Y^{*}\right)$ conditioned on the level of input used by the farmers (Ambali et al. 2012). Hence, the technical efficiency $\left(T E_{i}\right)$ of the farmer is expressed as:

$T E_{i}=Y_{i} / Y_{i}^{*}=f\left(X_{i} ; \beta\right) \exp \left(V_{i}-\mu_{i}\right) /$

$f\left(X_{i} ; \beta\right) \exp V=\exp \left(-\mu_{i}\right)$

The corresponding cost frontier of Cobb-Douglas functional form which is the basis for estimating the cost efficiency of the farmers is specified as:

$C_{i}=h\left(Q_{i} ; \alpha\right) \exp \left(V_{i}+\mu_{i}\right)$

Where $C_{i}$ : represents the total input cost of the $i^{\text {it }}$ farms, $h$ is the suitable function, pi represents input prices employable by the $i^{\text {th }}$ farm in food crop production measured in naira, $\alpha$ is the parameter to be estimated. V and $\mu$ are defined below. The cost efficiency (CE) of individual farmers is defined in terms of the ratio of the predicted minimum cost $C_{1}^{*}$ to observed $\operatorname{cost}\left(\mathrm{C}_{\mathrm{i}}\right)$. That is:

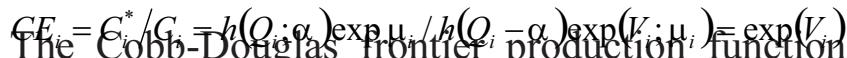
defined as follows: $\ln Y_{i}=\beta_{0}+\beta_{1} \ln X_{1}+\beta_{2} \ln X_{2}$
${ }_{4}+\beta_{5} \ln X_{5}+\beta_{6} X_{6}+\mu_{i}+V$ 
Where ln natural logarithm, $Y_{i}=$ rice output $\mathrm{kg}, \mathrm{X}_{1}=$ farm size (ha) $X_{2}=$ family labour (mandays), $X_{3}=$ hired labour (mandays), $X_{4}=$ seed $(\mathrm{kg}), \mathrm{X}_{5}=$ fertilizers $(\mathrm{kg}) \mathrm{X}_{6}=$ herbicides (litres). $V$ is assumed to be independent and identically distributed random errors having normal $\mathrm{N} \sim(0, \delta \mathrm{v} 2)$ distribution and independent of $\mu_{i} \cdot \mu_{\mathrm{i}}=$ deviation from maximum potential output attributed to technical inefficiency. The $\mu$ s are assumed to be non -negative truncation of the half - normal distribution $\mathrm{N} \sim(\mu, \delta \mu 2) \beta_{0}=$ Intercept $\beta_{1}$.

$\beta_{6}=$ Production function parameters to be estimated $\mathrm{i}=1,2,3, \ldots \mathrm{n}$ farms.

The Cobb-Douglas cost frontier function for the rice farmers is specified as:

$\ln C_{i}=\beta_{0}+\beta_{1} \ln P_{i}+\beta_{2} \ln P_{2}+\beta_{3} \ln P_{3}+\beta_{4} \ln P_{4}+$ $\beta_{5} \ln P_{5}+\beta_{6} \ln Y_{i}^{*}+V_{i}-\mu_{i}$

Where: $C_{i}=$ Total production cost of the $\mathrm{i}^{\text {th }}$ farms; $P_{1}=$ Wage rate of family labour per man day; $P_{2}=$ Wage rate of hired labour per man day; $P_{3}=$ Average price of seeds; $P_{4}=$ Price of fertilizer per $\mathrm{Kg}$; $P 5=$ Average price of herbicides per litre; $Y_{i}^{*}=$ Frontier Output of the $i^{\text {th }}$ farms; $Y_{i}^{*}=Y_{i} / T e_{i}$

The technical and cost inefficiency effect is defined

$\mu_{i}=\delta_{0}+\delta_{1} Z_{1}+\delta_{2} Z_{2}+\delta_{3} Z_{3}+\delta_{4} Z_{4}+\delta_{5} Z_{5}+\delta_{6} Z_{6}+\delta_{7} Z_{7}+\delta_{8} Z_{8}$ Where: $Z_{1}=$ Age of the farmer (years), $Z_{2}=$ years of formal education, $Z_{3}=$ farming experience (years), $\mathrm{Z}_{4}=\operatorname{Sex}(1=$ male; 0 otherwise $), Z_{5}=$ off-farm income $(N), Z_{6}=$ Household size (number of people), $Z_{7}=$ Number of extension contact, $Z_{8}=$ Farm distance to market $(\mathrm{km})$

The farmer's Allocative efficiency $\left(\mathrm{AE}_{\mathrm{i}}\right)$ was estimated as the inverse of cost efficiency following (Ambali et al., 2012). Thus:

$A E_{i}=1 / C E_{i}$

The Economic efficiency of the farmers was estimated as the product of technical efficiency and allocative efficiency $E E_{i}=A E_{i} * T E_{i}$

\section{RESULTS AND DISCUSSION}

Socio-economic characteristics of rice farmers The socio-economic characteristics discussed in this chapter include age, sex, marital status, educationa attainment, household size, farm size and fish farming experience.

Age is important to farming because it determines the agility and physical strength of the farmers. Result on Table 1 show that the age of the rice farmers ranges between 25 to 78 years with a mean value of 47 years. This implies that majority of farmers were middle aged with high probability of increased productivity in rice production. This finding agreed with Idiong et al. (2007) and Ibitoye et al. (2012). Labour productivity is a function of age as old people tend to adhere strictly to traditional methods of production while the younger folks tend to adopt new technology to enhance crop output.

The results of the study indicated that male farmers dominate the rice production industry in Oyo State as earlier observed by Ibrahim et al. (2008), and to the fact that in most societies the core agricultur production activity is the sole responsibility of me who are household heads while crop processing and marketing are handled by women. Ugwuanyi al. (2008) confirmed this when they reported highest percentage of females in locally milled rice marketing. However, this findings contradicts the report of Ibitoye et al. (2012) who found that there were more female rice farmers than males in Ibaji Local Government Area of Kogi State

\begin{tabular}{|c|c|c|c|}
\hline Variables & Frequency & Percentage & Mean \\
\hline \multicolumn{4}{|l|}{ Age } \\
\hline $25-30$ years & 14 & 10.9 & \\
\hline $31-40$ years & 27 & 21.1 & \\
\hline $41-50$ years & 34 & 26.6 & 47 \\
\hline $51-60$ years & 40 & 31.3 & \\
\hline Above 60 years & 13 & 10.2 & \\
\hline \multicolumn{4}{|l|}{ Sex } \\
\hline Male & 113 & 88.3 & \\
\hline Female & 15 & 11.7 & \\
\hline \multicolumn{4}{|l|}{ Marital status } \\
\hline Single & 12 & 9.4 & \\
\hline Married & 111 & 86.7 & \\
\hline Widow/Widower & 5 & 3.9 & \\
\hline \multicolumn{4}{|c|}{ Educational qualification } \\
\hline None & 28 & 21.9 & \\
\hline Primary & 28 & 21.9 & \\
\hline Secondary & 54 & 42.2 & \\
\hline Tertiary & 15 & 11.7 & \\
\hline Others & 3 & 2.3 & \\
\hline \multicolumn{4}{|l|}{ Household size } \\
\hline $1-3$ members & 16 & 12.5 & \\
\hline 4- 6 members & 58 & 45.3 & 6 \\
\hline 7 - 9 members & 42 & 32.8 & \\
\hline $10-12$ members & 12 & 9.4 & \\
\hline \multicolumn{4}{|c|}{ Area of land cultivated } \\
\hline 0.1 - 1 hectare & 63 & 49.2 & \\
\hline $1.1-2$ hectares & 46 & 35.9 & \\
\hline $2.1-3$ hectares & 13 & 10.2 & 2.6 \\
\hline Above 3 hectares & 6 & 4.7 & \\
\hline \multicolumn{4}{|c|}{ Rice farming experience } \\
\hline $1-10$ years & 73 & 57.0 & \\
\hline $11-20$ years & 41 & 32.0 & 11 \\
\hline $21-30$ years & 12 & 9.4 & \\
\hline $31-40$ years & 2 & 1.6 & \\
\hline Total & 128 & 100.0 & \\
\hline
\end{tabular}

Oladoja et al (2008) pointed out that marriage is highly cherished among the local farmers' communities. He asserts that marriage confers some level of responsibility and commitment on individual who are married. The marital status of the surveyed farmers shows that majority (about 87\%) of them are married Marrying more than one wife is common in rural settings mostly to ensure supply of additional family labour or to raise the status of the farmer in a local setting.

Education is of great importance in decision making. It can indirectly influence the farmers understanding of rice production and ways to maximize gains. About $78 \%$ of the farmers had on form of education or the other while about $22 \%$ of them had no formal education. Education could affect farmers' chances of using improved inputs which can boost rice output. As ealier observed by Mohammed-Lawal et al., (2009), handling of most Moher killed training and reading manuals for proper understanding of their operations.

Household size may determine the family labour at 
the disposal of a rice farmer. The result of the analysis showed that the mean household size of the respondents was about 6 persons. Majority $(45.3 \%)$ of the 6 persons between 4 and 6 persons. This implies that family abour is recognized as a major source of labour supply in Oyo State as it determines the labour output. Household size is very important when efficiency of farmers is discussed because it determines the dependency ratio, as well as consumption rate.

Farm categorization is justified only in the context of the particular environment. Majority $(49.2 \%)$ of the farmers cultivated between 0.1 and 1 hectare of farmland about $35.9 \%$ of them cul farmland, about $35.9 \%$ of 1.1 and 2.0 hectar armers cultivated above 2 hectares of farmland. The mean farm size was 2.6 hectares. The result implies that most of the rice farmers in the study area had relatively small farm holdings and hence were small - scale farmers.

Farming experience is used as a measure of management ability, the more experienced the farmer is, the more his ability to make farm fecision in the mrode his ability to farmers have been into inceproduction for about 1 10 years. $32.0 \%$ of the respondionts have been producing rice for about 11- 20 years while only $11.0 \%$ have been in the business for a period of 20 years and above, with a mean farming experience of 11 years. This shows that the managerial ability of the farmers can be inferred to be reasonably good.

Technical efficiency of rice farmers

The production function for rice based on the maximum likelihood estimates (Table 2) showed that farm size, hired labour, fertilizer and herbicides ll had significant effect on the output of rice. All the inputs except herbicides affected the output positively which is in accordance with a priori expectation. The negative coefficient of herbicides is against a priori expectation as the sign indicates that increase in the quantity of herbicides used will reduce the level of rice output.
The log-likelihood ratio test which is asymptotically distributed asa chi-square random variable was significant $(\mathbf{P}<0.01)$ indicating the inters in variach in the output of variation in the output of rice from productio frontier was due to the technical inefficiency of the production system. The coefficient of farm size, hired labour and fertilizer were positive which conform to a priori expectation. This implies that an increase in these variables would result in increase in output, Certeris paripus.

Six (6) variables (formal education, farming experience, sex, household size, extension agent exp

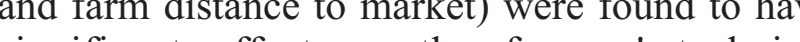
significant effect on the farmers' technical ineficiency. Only sex was significant at $10 \%$ leve of significance, the remaining five (5) variables being marginally significant at $1 \%$ level. Positive sign indicates that the inefficiency of the farmers increased as the variable increased and vice versa for negative sign.

Higher level of education of the farmers led to lower technical inefficiency. This is because; education brings enlightenment and exposes the the (a) ceisions and to to mation means, intensifying efforts to provide both adult and extension education to rice farmers would minimize inefficiency in resource use to boost rice production in the study area

Table 2: MLE of the parameters in stochastic production frontier analysis $(n=128)$

\begin{tabular}{lccc}
\hline Variables & Coefficient & Standard error & t-ratio \\
\hline Constant & $0.746^{*}$ & 0.462 & 1.617 \\
Farm size & $0.682^{* * * *}$ & 0.062 & 10.996 \\
Family labour & -0.019 & 0.020 & -0.978 \\
Hiredlabour & $0.864^{* * * *}$ & 0.051 & 17.027 \\
Rice seed & -0.022 & 0.038 & -0.583 \\
Fertilizers & $0.106^{* * * *}$ & 0.021 & 4.981 \\
Herbicides & $-0.063^{* * *}$ & 0.025 & -2.534 \\
Inefficiency & & & \\
Constant & -2.023 & 1.566 & -1.292 \\
Age & 0.115 & 0.596 & 0.193 \\
Formal Education & $-9.608^{* * * *}$ & 0.619 & -15.521 \\
Farming Experience & $-2.066^{* * *}$ & 0.163 & -12.653 \\
Sex & $0.866^{*}$ & 0.473 & 1.831 \\
Off-Farm Income & 0.231 & 0.182 & 1.278 \\
Household size & $-2.005^{* * * *}$ & 0.127 & -15.793 \\
Extension contact & $-0.596^{* * * *}$ & 0.221 & -2.702 \\
Farm distance to market & $-0.441^{* * * *}$ & 0.113 & -3.887 \\
Sigma-squared & $0.234^{* * * *}$ & 0.032 & 7.411 \\
Gamma & $0.438^{* * * *}$ & 0.090 & 4.886 \\
\hline Source Fied & &
\end{tabular}

Source: Field survey, 2017

In the same vein, farming experience correlates negatively with the farmers' inefficiency in the rice production, due to acquisition of relevant skills over the years. This result agrees with the findings of Ahmadu and Erhabor (2012).Increased household size reduces inefficiency of the farmers in rice production, corroborating the findings of Tiamiyu et al.(2008) and Ahmadu and Erhabor

efficiency through labour contribution to production operations. The inefficiency mode further revealed that sex, extension contact and distance of farm to market positively enhance the technical efficiency of the farmers.

As shown on Table 3, the study considered six variable inputs: family labour, hired labour, rice seeds, fertilizer, herbicides and rice output to estimate the cost efficiency.

\section{Table 3: Brief description of the data set}

\begin{tabular}{lrrrr}
\hline Variables & Mean & Min & \multicolumn{1}{c}{ Max } & \multicolumn{1}{c}{ SD } \\
\hline Family labour & $14,445.05$ & - & $30,000.00$ & 302.48 \\
Hiredlabour & $35,018.00$ & $20,000.00$ & $50,000.00$ & 9045.94 \\
Rice seed & $25,200.00$ & $25,000.00$ & $30,000.00$ & 10014.25 \\
Fertilizers & $45,600.00$ & $20,000.00$ & $70,000.00$ & 4454.29 \\
Herbicides & $33,500.00$ & $15,000.00$ & $50,000.00$ & 5459.89 \\
Rice output & $522,664.80$ & $255,000.00$ & $757,500.00$ & 47401.71 \\
\hline Source:Field & & & &
\end{tabular}

Source:Field survey, 2017

\section{Cost efficiency of rice farmers}

The estimated parameters for the stochastic cost rontier for rice production presented in Table 3 revealed that $\sigma 2(0.325)$ and $\gamma(0.760)$ were significantly different from zero at $1 \%$ level of probability. The sigma squared $(0.325)$ was significantly different from zero at $1 \%$ which indicates a good fit and correctness of the
distribution form assumed for the composite error distribution form assumed for the composite error term. The gamma estimate of 0.76 , shows the resulting from the cost efficiencies of the rice 
farmers. This means that $76 \%$ of the variation in the total cost of production of rice farmers was due to cost efficiency.

All the coefficients of the variables examined in the cost function have positive signs with the exception of wage rate of family labour and price of fertilizer. The result showed that hired labour wage rate $(p<0.01)$, average price of seed $(p<0.01)$ and , optimum output $(p<0.05)$, positively increase the
total cost of rice production.

The inefficiency model showed that formal education, off farm income and extension contact had significant effect on the cost efficiency of the

rice farmers, being significant at 1 percent, 10 percent and 1 percent respectively. While forma education and extension contact have negative effect on cost efficiency, off farm income has positive effect on the cost efficiency of the farmers. This implies that the cost efficiency of the farmers decreases with increase in farmer's education an extension contact while farmers' economic exteiency increases with increased formal education and extension contacts. Lastly, the more the anount of off-farm income the more the farmers are cost efficient but the lesser they are economically efficient.

Table 3: MLE of the parameters in stochastic cost frontier analy sis $(n=128)$

\begin{tabular}{lccc}
\hline Variables & Coefficient & Standard error & t-ratio \\
\hline Constant & $1.946^{* * * *}$ & 0.273 & 7.139 \\
Wage rate of family labour & -0.107 & 0.139 & -0.771 \\
Wage rate of hired labour & $0.440^{* * * *}$ & 0.027 & 16.371 \\
Average price of seeds & $0.790^{* * * *}$ & 0.261 & 3.025 \\
Price of fertilizer per Kg & -0.024 & 0.042 & -0.569 \\
Average price of herbicides per litre & 0.035 & 0.022 & 1.605 \\
Frontier Output of the $i^{\text {th }}$ farms & $0.462^{* * * *}$ & 0.025 & 18.633 \\
Inefficiency & & & \\
Constant & -0.881 & 3.832 & -0.230 \\
Age & -1.043 & 0.648 & -1.610 \\
Formal Education & $-3.554^{* * * *}$ & 1.031 & -3.446 \\
Farming Experience & -0.106 & 0.069 & -1.531 \\
Sex & -0.229 & 1.625 & -0.141 \\
Off-Farm Income & $0.451^{* *}$ & 0.246 & 1.833 \\
Household size & -0.082 & 0.125 & -0.657 \\
Extension contact & $-1.513^{* * * * *}$ & 0.321 & -4.716 \\
Farm distance to market & 0.302 & 0.330 & 0.915 \\
Sigma-squared & $0.325^{* *}$ & 0.188 & 1.732 \\
Gamma & $0.760^{* * *}$ & 0.098 & 7.748 \\
\hline Souce:Field & & &
\end{tabular}

Source:Field survey, 2017

\section{Efficiency estimates of rice farmers}

The frequency distribution of Technical efficiency, Allocative efficiency and Economic efficiency Estimates of the rice farmers are presented in Table 4. The technical efficiency of the rice farmers is fairly distributed with $87.5 \%$ having their efficiency within the bracket of 0.81 and 1.00 . This gives a mean technical efficiency of 0.885 implying there is room for improvement in technical efficiency by $11.5 \%$ with the present technology. The allocative efficiency estimates of the rice farmers are ranged between 0.08 and 0.93 with the mean efficiency of 0.82 . This implies there is room for improvement by $18 \%$.

The economic efficiency estimates of the rice farmers are ranged between 0.07 and 0.89 with the mean efficiency of 0.77 . The implication of this is minimum cost. In addition, the mean economic efficiency of the farmers shows there is room for improvement by $23 \%$. that the farmers averagely produce rice output at a

\begin{tabular}{|c|c|c|c|c|c|c|}
\hline \multirow[t]{2}{*}{ Class } & \multicolumn{2}{|c|}{ Technical efficiency } & \multicolumn{2}{|c|}{ Allocative efficiency } & \multicolumn{2}{|c|}{ Economic efficiency } \\
\hline & Freq & $\%$ & Freq & $\%$ & Freq & $\%$ \\
\hline$=0.50$ & 2 & 1.6 & 16 & 12.5 & 29 & 22.7 \\
\hline $0.51-0.60$ & 2 & 1.6 & 24 & 18.8 & 42 & 32.8 \\
\hline $0.61-0.70$ & 4 & 3.1 & 32 & 25.0 & 33 & 25.8 \\
\hline $0.71-0.80$ & 8 & 6.3 & 25 & 19.5 & 23 & 18.0 \\
\hline $0.81-0.90$ & 26 & 20.3 & 28 & 21.9 & 1 & 0.8 \\
\hline $0.91-1.00$ & 86 & 67.2 & 3 & 2.3 & - & - \\
\hline Total & 128 & 100.0 & 128 & 100.0 & 128 & 100.0 \\
\hline Mean & \multicolumn{2}{|c|}{0.885} & \multicolumn{2}{|c|}{0.669} & \multicolumn{2}{|c|}{0.583} \\
\hline Minimum & \multirow{2}{*}{\multicolumn{2}{|c|}{0.164}} & \multicolumn{2}{|c|}{0.082} & \multicolumn{2}{|c|}{0.077} \\
\hline Maximum & & & \multicolumn{2}{|c|}{0.936} & \multicolumn{2}{|c|}{0.885} \\
\hline
\end{tabular}

Source: Field survey, 2017

\section{CONCLUSION AND RECOMMENDATIONS}

The findings of the study revealed that majority of the rice farmers had formal education. The stochastic production function revealed that rice output increases with farm size, hired labour, and fertilizer but decreases with herbicide implying the rice farmers over-utilized herbicide.

The mean technical efficiency of $91 \%$ showed that there is potential to increase output by $9 \%$ with the present technology. The mean allocative efficiency of $82 \%$ implies there is room for improvement by $18 \%$. More $18 \%$. $74 \%$ implies there is roon for inprovement $26 \%$. The results further revealed that provision of input
credit, formal education, household size and farmers experience in growing rice are some of the significant factors that influence efficiency.

Policy option requires the rice farmers to reduce the use of herbicides. Farmers should expand their farm land to ensure efficient utilization of resources, formal education and adult literacy education should be strengthened anong the rice education should be stengthened anong the rice farmers. There is need for farme to be given proper orientation and/or basic training in major farm management techniques most especially participation in programmes that address efficient allocation of production resources. This will help increase their level of profitability, hence, be more efficient. Rice production has great potentials in the study area. Government should formulate policies that will create an enabling environment and attract more youths to invest in rice farming production. This will create room for new ideas and increas level of productivity by the farmers towards achieving food security.

\section{REFERENCES}

Ahmadu, J. and Erhabor, P. O (2012).Determinants of technical efficiency of rice farmersin Taraba State, Nigeria. Nigerian Journal of Agriculture, Food and Environment. 8(3):78-84

Ajoma, C., Ezihe,J.A.C. and Odoemenem, I.U (2016). Allocative Efficiency of Rice Production in Cross River State, Nigeria: A Production Function Approach. IOSR Journal of Agriculture and Veterinary Science (IOSR-JAVS) 9(8);32-38

Ambali O. I., Adegbite D. A., Ayinde I. A. and Awotide D. O. (2012). Analysis of Production Efficiency of Food Crop Farmers in Ogun State, Nigeria. ARPN Journal of Agricultural and Biological Science. 7(9); 680-688

Coelli, T.J., Rao, D.S. O'Donnell, C.J. and Battese, G.E., (2005). "An Introduction to Efficiency and Productivity Analysis", Second Edition, Springer Science + Business Media, New York, USA

FAO, (2012). International Rice Commission newsletter. http://www.fao.org

Fasasi A. R. (2007). Technical Efficiency in Food Crop Production in Oyo State, Nigeria, $J$. Hum. Ecol., 22(3): 245-249

Ibitoye, S.J., Orebiyi, J.S. and Shaibu, U. M (2012) Economic Effect of Inorganic Pesticide Use on Fadama II Rice Farming in Ibaji Local Government Area, Kogi State, Nigeria. 
International Journal of Agric. and Rural Development, SAAT, FUTO. 15 (2):1063 1070.

Ibrahim, F.D.; Z.S. Alhassan; M. Ibrahim and P.A. Ibrahim (2008). Private Sector (Candell Company) and Boosting Rice Production: A Case Study of R-Box Technology Adoption in Badeggi, Bida LGA of Niger State.In: Aiyedun E.A; P.O. Idisi and J.N. Nmadu (eds), Proceedings of 10th Annual National Conference of Nigerian Association of Agricultural Economists Association of Agricultural Economists
(NAAE) held at University of Abuja, Abuja, Nigeria,7th-10th October, pp.136-144.

Idiong .I.C. (2007). Estimation of Farm Level Technical Efficiency in Small scale Swamp Rice Production in Cross River State of Nigeria: A Stochastic Frontier Approach. World Journal of Agricultural Sciences 3(5): 653-658.

Kadiri, F. A.; Eze, C.C; Orebiyi, J. S; Lemchi, J. I;Ohajianya, D. O; Nwaiwu, I. U (2014).Technical Efficiency in Paddy Rice Production in Niger Delta Region of Production in Niger Delta Region of
Nigeria. Global Journal of Agricultural Research. 2:(2);33-43

Muhammed-lawal, A., O.A. Omotesho and A. Falola (2009). Technical Efficiency of Youth participation in Agriculture Programme in Ondo State, Nigeria. Nigerian Journal of Agriculture, Food and Environment. 5(1):20-26

Munonye Jane .O (2016). Nigeria Rice Imports in the last Three Decades under different Trade and Fiscal Policies. Unified Journal of Agriculture and Food Science 2(1): 001008

Ogundari, K., and Ojo, S.O. (2007).Economic efficiency of small scale food crop productionin Nigeria: A stochastic frontier approach. Journal of social sciences 14(2): 123-130.

Okoruwa, V.O., Ogundele, O. O. and Oyewusi, B.O. (2006). Efficiency and productivity of farmers in Nigeria: A study of rice farmers in North Central Nigeria. A poster paper prepared for presentation at the
International Association of Agricultural Economists Conference, Gold Coast, Australia, August, 12- 18, 2006

Oladeebo J.O. and A. A. Fajuyigbe (2007) Technical Efficiency of Men and Women Upland Rice Farmers in Osun State, Nigeria. J. Hum. Ecol., 22(2): 93-100

Oladimeji Y. U. and Z. Abdulsalam (2013).Analysis of Technical Efficiency and Its Determinants among Small Scale Rice Farmers in Patigi Local Government Area of Kwara State, Nigeria. IOSR Journal of Agriculture and Veterinary Science(IOSR-JAVS) 3(3); 34-39

Oladoja, M. A., Adedoyin, S. E and Adeokun, O. A., (2008). Training needs of fisher folks on fishing technologies. Journal of Food Agriculture and Environment Science and Technology. 6(1); 195 - 198

Osanyinlusi, O. I. and Adenegan, K. O. (2016). The Determinants of Rice Farmers' Productivity in Ekiti State, Nigeria Greener Journal of Agricultural Sciences. 6(2); 049-058

Oyekanni A A, Okeleye K.A, and Okomji C.T (2008). On-farm evaluation of rain fed lowland rice varieties at Olokose village, Odeda, Ogun State. Nigerian Journal of Agronomy 7(2): 192-196

Tiamiyu, S. A.; J. O. Akintola and M.A.Y. Rahyi (2008). Potential for Rainfed Upland Rice Productivity Growth in Guinea Savannah Zone of Nigeria. In: Aiyedun, E.A.; P.O. Idisi and J.N. Nmadu (eds), Proceedings of 10th Annual National Conference of NAAE held at University of Abuja, Abuja, Nigeria, 7th-10th October, pp.267-275

Ugwuanyi, C. A.. Balogun, O. S. Akinyemi,, O. G. Balogun, F. and Zungum, A. (2008). Cost and Returns of Small-Scale Locally Milled Rice Marketing in Uzo-Uwani LGA of Enugu State. In: Aiyedun, E.A.; P.O. Idis and J.N. Nmadu (eds) proceedings of 10th Annual National Conference of NAAE held at University of Abuja, Abuja, Nigeria, 7th-10th October, pp.78-85. 